This item was submitted to Loughborough's Research Repository by the author.

Items in Figshare are protected by copyright, with all rights reserved, unless otherwise indicated.

\title{
The role of knowledge management in development projects
}

PLEASE CITE THE PUBLISHED VERSION

http://dx.doi.org/10.1142/S0219649211003024

\section{PUBLISHER}

(c) World Scientific Publishing Co.

\section{VERSION}

AM (Accepted Manuscript)

\section{LICENCE}

CC BY-NC-ND 4.0

\section{REPOSITORY RECORD}

Oluikpe, Paul, M. Sohail, and Frank Odhiambo. 2019. "The Role of Knowledge Management in Development Projects". figshare. https://hdl.handle.net/2134/9316. 
This item was submitted to Loughborough's Institutional Repository (https://dspace.lboro.ac.uk/) by the author and is made available under the following Creative Commons Licence conditions.

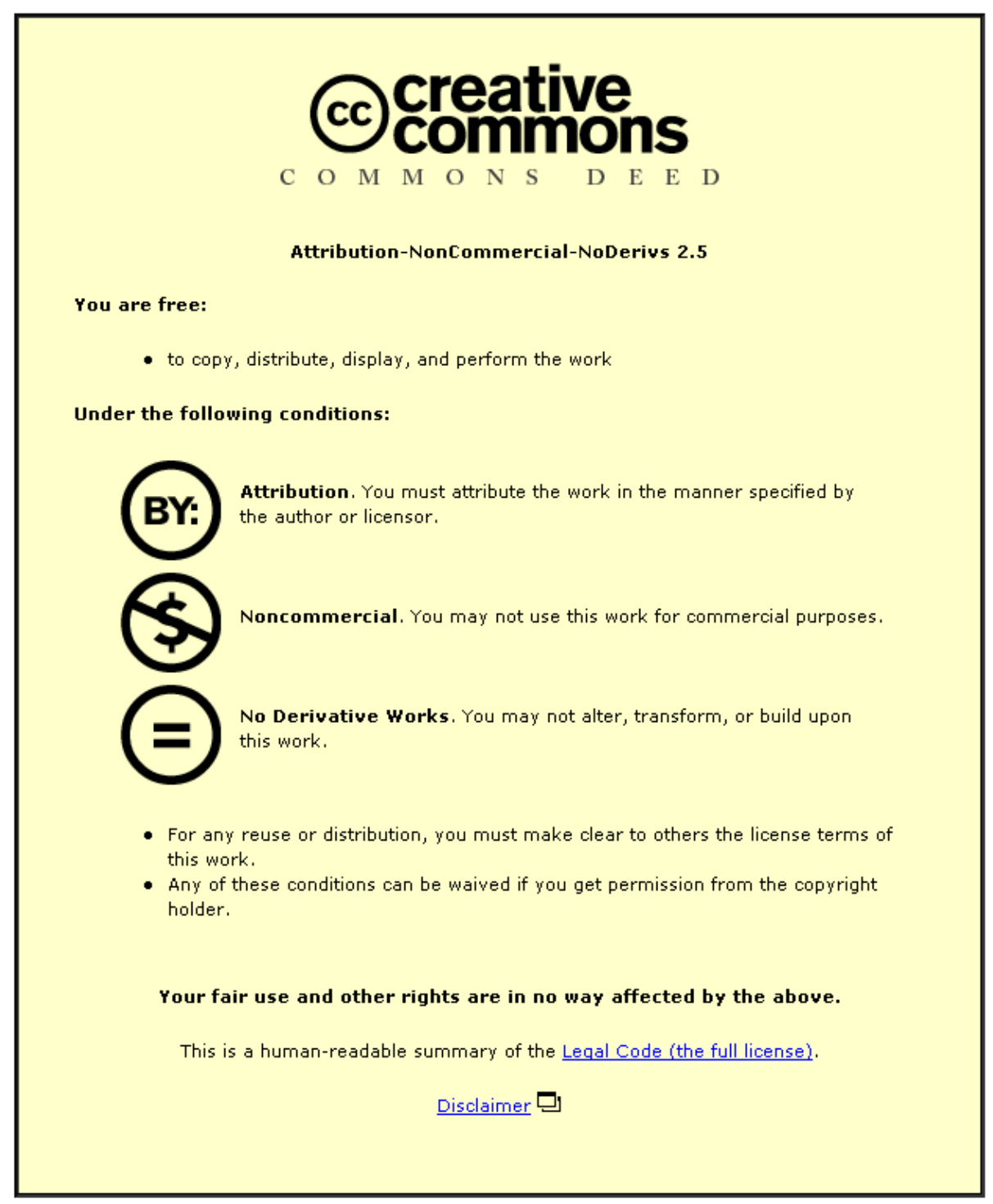

For the full text of this licence, please go to: http://creativecommons.org/licenses/by-nc-nd/2.5/ 


\title{
The role of knowledge management in development projects
}

\begin{abstract}
The paper investigates the role of knowledge management in enabling project success, innovation, completion times, operational efficiency and the generation of new knowledge in development projects. Four projects in Uganda, Nigeria, and Cote d'Ivoire were used as case studies. The objective was to explore the nature of knowledge management practices in these projects in order to see how they could be improved. The research found that knowledge management is a significant factor in speeding up completion times, achieving project success, innovation, operational efficiency and the generation of new knowledge. Knowledge sharing practices were identified within case studies and difficulties relating to managing knowledge generated during the project were highlighted.
\end{abstract}

Keywords: Knowledge management; development projects; project management; international development.

Paper Type: Research 


\section{Introduction}

This paper investigates the role of knowledge management $(\mathrm{KM})$ in enabling development project teams to achieve objectives. Development Projects (DPs) like any other business activity, have a difficulty with managing what they know and this has an impact on project outcomes. Poor management of knowledge critical to a project can result in failure to achieve project outcomes. To realise intended outcomes, project teams need to : focus on the project process; capture knowledge at each stage of the project; enable learning; and ensure completed projects feedback into new projects (Cusworth and Franks, 1993).

\subsection{Knowledge Management and the underlying concepts}

Given the multidisciplinarity of $\mathrm{KM}$, it comes as no surprise that various definitions come from different angles and perspectives. Some come from strategic management perspective (Wiig, 1997, 2000; Alavi and Leidner,2001), others come from a human resources perspective (Skyrme and Amidon, 1997; Liebowitz, 2001) while others come from information systems angle recognising that $\mathrm{KM}$ is a tool for making meaning out of information (Kakabadse et al, 2003; Lave, 1988; Blacker, 1995). However, none of these definitions are clear on their positions on the highly turbulent environments of development project management which require continuous innovation, efficiency and faster delivery (completion) times (Newell et al., 2002).

A knowledge management definition is offered here by this paper. Knowledge management can be defined as: the systematic process of creating, exploiting and sharing individual, corporate and team knowledge (tacit and explicit) utilising technology, culture, strategy and people in enhancing innovation, efficiency, completion times and organisational performance.

This definition recognises and embraces the need to manage knowledge efficiently in highly turbulent development project environments.

A variety of concepts and influences have contributed to the evolution of $\mathrm{KM}$ to an organisational strategy and as a discipline worthy of scholarly investigation.

\subsection{The concept of tacit and explicit knowledge}

Knowledge management discourse in the current dispensation has been dominated by the two types of knowledge-tacit and explicit knowledge. Nonaka and Takeuchi's (1995) seminal work on knowledge management served to popularise these concepts. The notions of tacit and explicit knowledge could be traced back to Gilbert Ryle (1900-1976) and Michael Polanyi (1891-1976). Their viewpoints and philosophies are represented in Figure 1 below. 


\section{(Insert figure 1 here)}

Ryle contributed mostly towards the understanding of "knowing how" (tacit) and "knowing that" (explicit). Polanyi comes from a similar background as Ryle and his contribution towards the concept of tacit and explicit knowledge borders on the idea that "we know more than we can tell". Tacit knowledge is the basis of actions-knowing how to do a thing while explicit knowledge is action that is dormant. Nonaka and Takeuchi's (1995) work on tacit and explicit knowledge elaborated on the relationships between the two kinds of knowledge and surmised that one can be converted into the other. These two philosophical viewpoints affected the ideas and writings that followed. Presently, the notion of tacit knowledge is said to be based on the empiricist perspective of "doing" while the notion of explicit knowledge is based on the idealist perspective of "being". Idealistic postulations of knowledge are existentialist while empiricist postulations are pragmatic. There is yet no universally accepted definition of knowledge. Definitions have tended to follow one of the two perspectives described above. Styhre and Kalling (2003) explained that the reason why there would be no final coherent definition of knowledge is because mainstream knowledge management theorists are not that interested in knowledge per se but rather care more about management.

\section{$1.3 \mathrm{KM}$ models and processes}

Many models and processes of $\mathrm{KM}$ covering a wide spectrum of viewpoints exist in the literature. Notable among these are (1) Nonaka and Takeuchis' (1995) model which represents a knowledge creation process; (2) Boisot's (1987) model which considers knowledge as either codified or uncodified and diffused or undiffused; and (3) Demerests (1997) model which highlights the construction of knowledge within the organisation not limiting the process to scientific approach alone but also involves the social construction of knowledge.

In the following subsection, we particularly critique the CAPRIKON model due to it's' usefulness in elaborating the knowledge processes and the comparisons between other similar processes.

\section{CAPRIKON}

\section{(Instert Table 1 here)}

Table 1 above depicts the CAPRIKON model by Tan et al (2006) and compares it with other typical knowledge processes. According to this model, knowledge capture encapsulates identifying and locating knowledge and knowledge representation involves storing and validating knowledge. Knowledge sharing deals with the transfer of knowledge to the right people at the right time (Robinson et al, 2001). Knowledge transfer is a transactional process 
involving the exchange of information between people. Information can be exchanged through media such as computers, word of mouth, writings, visuals and audio. The next step in the knowledge process is knowledge reuse. This process involves adapting and applying knowledge gained for problem solving. Ideas could be reused and applied for innovative ends through developing such ideas fully and reconceptualising the problems they are meant to solve. In this way, there is a continual flow of knowledge in a cycle leading to use and reuse and in each scenario, the knowledge adapted and used emerges in a different and improved form. Knowledge reuse leads to its maintenance which relates to archiving and retiring for subsequent use. It also involves updating and refining it to keep abreast of developments in the area.

\section{Development projects: an overview}

A development project is a project intended to increase a developing country's ability to produce in the future. Such projects are most commonly additions to the country's capital stock, but they may involve improvements in infrastructure, educational facilities, discovery or development of natural resources, capacity building, human development, and economic empowerment (Deardorff, 2000). Development projects in this sense could encapsulate several disciplines or thematic areas as long as the endeavour is aimed at increasing a developing country's capacity to sustain itself. As in the foregoing, the inexistence of boundaries in discipline or thematic areas makes DPs a very wide area of activity (McMichael, 2004; Bennet, 2000).

Development projects are tied to the conditions that created them. As a result, there are various challenges that are unique to them:

\subsection{Challenges facing development projects}

A number of challenges face development projects as outlined below:

Accountability: Development projects have been criticised for being unaccountable to clients and beneficiaries (Burger and Owens, 2006). In the past, development interventions have tended towards coming from external sources with beneficiaries having little input into how the project is designed. This makes the project vulnerable and susceptible to failure. It might also engender suspicion and hostility from the host communities and a misunderstanding of the real motives of the project.

The challenge of knowledge reuse: Due to the temporary nature of projects, teams most often disband at the end of the project while reviews are hastily done, not often with the intention of 
reusing the knowledge in future projects. The most important factor in carrying out reviews, as literature suggests is to comply with project monitoring requirements. There is a frequent suggestion in literature that projects do not often reuse the lessons learned from previous projects (von Zedtwitz, 2003). This arises from what Tan Hai et al., (2006), Carrillo (2005) and Garon (2006) highlighted as the inability of projects to capture, codify and carry over knowledge into future projects.

Turbulence, change and complexity: Development projects sometimes operate in highly volatile environments where conflict-political, religious and tribal, and natural disasters occur. They also operate in atmospheres of economic uncertainty especially in developing countries where politics and economic dynamics change very often. These situations necessitate constant adaptation, learning and knowledge sharing to survive and meet project objectives (Abom, 2004).

Ignorance: Development projects also operate in regions of the world where education and enlightenment are very minimal. The level of awareness of benefits that projects could bring may be very low and this may stir resistance to the project. A case in point is the resistance to the planned polio vaccination of indigenes of Northern Nigeria in 2004/2005 (Yahya, 2007).

Low national infrastructure: In developing countries, especially in Sub-Saharan Africa, the rate of technological and infrastructural development is low and does not meet acceptable minimum standards of development. As a result, it is difficult for projects operating in these areas to have access to good roads, fast Internet access, good transport, established markets and even raw materials for projects (Baker, 2000).

In addition to the challenges peculiar to development projects, there are also challenges facing Project Management in general.

\subsection{Current PM Challenges}

The literature of Project Management (PM) identifies a number of challenges unique to projects:

Innovation: Projects continually need to introduce new ideas to survive the increasingly complex project environment (Rogers and Kim, 1985). The paradigm of project innovation has shifted from single innovator to a network of heterogeneous actors all working together to generate innovative products. This has led to an emphasis on leveraging teams' innovative capabilities. The process of leveraging these capabilities is a challenge for Project Management (Downs and Mohr, 1976). The reason is that individual team members of a 
project have different discipline expertise, cultural exposure, skills and capabilities and to combine all these varying levels of skills, competencies and expertise to achieve project innovation will require complex processes, tools, techniques, leadership, management support and collaboration (Thompson, 1965; Rogers and Kim, 1985; Jacques and Ryan, 1978).

Completion times: Completion time is a major index for assessing project success. A project will be deemed as successful if completed on time, and met cost and quality standards. Literature reviewed established that there was about $50-80 \%$ delays on 1627 World Bank projects between 1974 and 1988 with an average of 23.2\% time overruns on UK government projects between 1993 and 1994. Project completion time can be measured as the extent to which the project is finished on schedule (Ancona and Caldwell,1992). Completing on time is a major constraint for projects due to the complexity and nature of project management. Based on the literature reviewed, the percentage of project overrun is very high and poses a challenge to Project Management. This has led to a rethink in traditional project management methods asapproaches to achieving results need to be constantly reviewed.

Project Success: A successful project is one that was on-time, on-budget, and that met client specifications. From a KM perspective, the measure of success is the amount of knowledge that could be carried on to future projects (Dalgleish, 2003). Traditional project success criteria are centred on cost, time and quality but de Witt (1998) and Jugdev and Muller (2005) argue that success in project management has moved beyond these three metrics. There is currently a holistic view of project success incorporating both tangible and intangible dimensions such as communication, teamwork and knowledge sharing.

Operational Efficiency: Operational efficiency may be defined as the optimal use and management of project inputs and processes in order to achieve the project's goals and objectives. Operational efficiency involves finding the best ways to deliver a project, eliminating repetitive and low-value tasks, reducing risk and improving quality and eliminating errors associated with certain manual or automated tasks. Organisations must examine baseline operational processes that support the project, and then plan, implement, and support the right procedures using KM processes (Von Krogh, Ichijo and Nonaka, 2000). It is a challenge for project teams to find the right mix of resources available to leverage capabilities (Brown and Eisenhardt, 1997).

Generation of New Knowledge: Knowledge creation is the process of realising new knowledge from the project process. Knowledge-based project management anchors project success to the creation and realisation of new knowledge and utilising these for future projects. This view reflects a KM approach to achieving project success. Innovation is often linked to the realisation 
and utilisation of new knowledge leading to cutting edge delivery of products and services. However, a major challenge for project teams is to understand 'how' and 'when' new knowledge is generated and how to utilise it to build capabilities (Holvland, 2003).

\section{Research design}

The research was conducted in cooperation with four organizations which carry out development projects in Africa. These organizations were interested in how to increase their competitiveness using knowledge management to leverage innovation, project success, operational efficiency, completion times and the generation of new knowledge. The goal was to explore KM activities within the projects and derive conclusions as to their impact on leveraging innovation, project success, operational efficiency, completion times and the generation of new knowledge. Case study 1 is a project dealing with poverty reduction in Nigeria. This project was chosen for its unique collaboration and team work strategy to project management. This uniqueness could provide important insight into how development project teams share knowledge. Case study 2 is an environmental project dedicated to the promotion of collective exploitation and share of common property resources such as fishing, land and other resources in the Jigawa Wetlands of Northern Nigeria. Its project strategy is aligned towards thematic areas with cross-functional outlook which the researchers felt will provide a rich environment for measuring knowledge management practices especially as relating to collaboration. Case Study 3 is a collaborative water resources project which aims to build the capacity of countries bordering the Nile to utilise the common resources of the Nile. It also aims to reduce conflict over the share of those resources such as fishing rights, irrigation and access to territorial waters. The choice of this case study lies on the regional and international collaboration outlook which necessitates the existence of distributed project teams across geographical boundaries. Knowledge exchange is an essential feature of this project. Finally, Case study 4 is a project dealing with networking, training and capacity building which serves the water utilities sector of Africa. Due to a continually shifting paradigm and changing environment, this project has recently repurposed and repositioned its strategic objectives to include knowledge management.

\section{(Insert Table 2 here)}

Since knowledge management activities can hardly be measured without exploring the characteristics of particular projects, their organizational framework, vision and goals, a case study research was chosen. The case study research adapted from Yin (1994) was developed and conducted. An interview framework was designed after literature review. This framework took into consideration the Knowledge Management processes of a project supported by 
Technology, Culture, People and Strategy-the four dimensions of knowledge management. This framework ensured that relevant $\mathrm{KM}$ activities and aspects were studied during the interviews.

The unit of analysis is a single project within an organization. The primary criteria for selecting projects for the study were knowledge intensity of the project, similarities in size, and the heterogeneity of project areas. The final case study selection was based on the presence of KM activities in documentation such as Post Project Reviews. Interviews of three to six people in each project were held during summer of 2007. These were conducted by one to two interviewers. Each interview lasted between 1.5 and 3 hours. Interviewers used the guidelines and paid attention to the specific contexts of each organization and asked questions exploring subjects in greater detail. Each interview was recorded on tape and transcribed. A 3 to 5 page summary based on the interviews and documentation received from the organizations was created for each project. The summaries were sent to the organizations for approval thereby allowing them to give feedback and clarifications where necessary. The details of the interview questions used during the process of collecting data from interviewees are presented in Table 2.

\section{(Insert Table 2 here)}

Yin (1994) suggests that the case study research strategy has a particular advantage when "a 'how' or 'why' question is being asked about a contemporary set of events over which the investigator has little or no control." Case study research has been subject to considerable criticism. Yin (1994) has identified three sources for this criticism. First, it arises from the potential lack of rigour. The researcher is solely in control of the systematic application of the research methods. Thus, the research quality is a function of the researcher. Second, the value of case studies for generalization tends to be modest. Third, case studies can be massive documents that are laborious to compile. As a result, it is difficult to know what is important and what data needs to be collected. The findings of case studies are based on logical and not statistical reasoning. The results of case studies are also dependent on the ability of the interviewees to present the KM activities of the project and the ability of the interviewer to correctly interpret the results. The findings of this study are therefore not necessarily generalizable to other projects. 


\section{Analysis and Results}

The impact of $\mathrm{KM}$ activities on the projects were evaluated and measured using five criteria: Innovation, completion times, project success, operational efficiency and generation of new knowledge. The size of the project, the geographical area of operation, stakeholders, and main audience of the knowledge management programme were taken into consideration. Two major considerations were made in gauging the impact of $\mathrm{KM}$ :

- Was the KM initiative contributing to the five critical areas being measured (i.e. innovation, project success, completion times, operational efficiency and the generation of new knowledge)?

- Were the KM activities making sufficient business impact?

The potential sustainability of the knowledge management initiative in the projects was measured by the usage of the KM systems and practices in the project. We tried to identify the level of support from top management of the KM program. Table 3 provides a more comprehensive view of the criteria applied to the cases.

\section{(Insert Table 3 here)}

Innovation: The results of analysis in the table above depict a shift from traditional project management practices to team-based and collaborative approach. This shift is suggestive of the perception that competitive advantage lies in sharing knowledge and leveraging innovative capabilities inherent in team-based project work. Across the case studies, innovation is mostly driven by team work, communities of practice and networking. This view confirms what knowledge management literature has been saying for the past decade, that innovation is linked to leveraging group capabilities (Carrillo, 2005; Abom, 2004; Rollet, 2003). Observed case study data indicate that social processes of knowledge creation are very significant to the innovation process. Social capital generation and the existence of communities of practice are very essential for innovative processes within projects. Development projects use communities of practice as a tool for project execution and organisational learning. KM practices are therefore viewed as very crucial to the project process. The case studies realize the importance of $\mathrm{KM}$ in their project process. This realisation is very important to creating a shift towards a knowledge-based PM paradigm. Case Study 3 builds its model of project execution on dialogue, collaboration and cooperative execution. This has worked well in this circumstance given the political and cultural issues at stake for the project (Marquis, 1969; Matthews, 1999).

Completion times: Completion times as reported by the case studies depend mostly on leveraging the knowledge base of projects through group mechanisms and translating this to tangible outcomes. The implication is that the knowledge sitting at the core of the project, 
especially among team members is a critical resource which if leveraged properly could help prevent project overrun. The impact of late project completion in terms of cost and resource utilisation is well documented in project management literature (de Wit, 1998; Winter et.al., 2006). Finding out whether KM affects the completion times of projects is not a straightforward process. Staff working on projects were asked to provide their views and perceptions about utilising knowledge to carry out projects faster. The more knowledge project staff have at their disposal, assuming there is a strategic intention to manage and share knowledge, the faster projects would be completed. The following factors were identified as reasons why projects complete on time:

1. Increased knowledge;

2. Improved infrastructure ;

3. Increased capacity and experience;

4. Organisational learning; and

5. Technology

These are factors linked to KM. Literature also supports the trend of response data gathered (Argyris, 1978; Garrick, 1998; Kerzner, 2001; Sena, 2000).

\section{Project success:}

The success tripod (Time, Cost and Quality) still remain the most important measures of success for DPs. The rate of knowledge generated during a project is a factor to its success. However, there is an increased tendency towards developing internal measures of success unique to the project. Project managers interviewed have different perceptions about what constitutes success for their project. KM is gaining recognition as a contributing factor to project success (Bresnen,Goussevskaia and Swan, 2003). Having a strategic plan of managing project knowledge and how to carry this over to future projects reflects a measure of success for the project. Knowledge-based projects would include KM processes of the project as a major index for measuring success. On the whole, there appears to be a lack of convention on KM measures and how this impacts on project success. Because KM deals with intangible resources, there is a difficulty putting it down as a measurable resource within the organisation. The case studies also reveal that organisations acknowledge the roles of KM in project success but there is little to suggest the existence of strategic frameworks to utilise knowledge generated during the project process. A strategic KM plan would include how to create and share knowledge and also how to manage what has been shared. KM should be systematic to make sense in organisations.

Operational efficiency: Interview responses indicate that efficiency relates to various areas of PM: design and development; people management; documentation; knowledge sharing; strategy; competition; organisational learning; process management; and technology selection, 
deployment and use (Nguyen, Ogunlana and Xuan Lan, 2004; Sena and Shani, 2000; Agarwal and Rathod, 2006). Responses reveal a difficulty defining what point the organisation is performing efficiently. The internal operations of the projects need to be consistently integrated and focused to impact on the project objectives. The implication is a bridge building KM strategy that would align major forces within the project, combine knowledge, integrate competences, and deliver required outcomes. The goal of $\mathrm{KM}$ is to assist the project process make meaning out of the information flowing in and out of the project. Careful project planning is the best lever for efficiency. Few project managers would argue against the case of optimising the efficiency of projects but few are actually willing to invest sufficient time and resources to actualise this. In the same vein, few managers would argue against the usefulness of $\mathrm{KM}$ in impacting on efficiency of operations however, when getting down to earth about KM programmes for a project, there is little evidence to suggest a conscious and strategic effort towards managing knowledge. Staff of projects interviewed acknowledged that operational efficiency is at the heart of quality projects. Case study 1 particularly has a quality assessment procedure which incorporates knowledge of past project procedures into current ones. Case study 2 incorporates quality planning at the design stage of each project, yet it does acknowledge having difficulties leveraging knowledge from other projects especially if staff have dispersed or staff have resigned or moved on. Case Study 3 has a strategic objective to continually increase quality of service delivery through capacity building. Technical support from donors have enabled the training of staff nationally and staff trained in turn become facilitators. This has enhanced the level of efficiency of service. Planning for efficiency could involve KM considerations as it relates to the product quality, effective project process and staff involvement in the project. 
Generation of New Knowledge: Analysis of the results of interviews and documentation show that realising new knowledge in a development project is hinged on how they codify knowledge from communities of practice and post project reviews. The process of capturing, transforming, analysing and making sense of knowledge using technology enables the creation of new knowledge. The CAPRIKON model elucidates the process of knowledge creation (Tan et al., 2006) and this is consistent with observed data from case studies. Furthermore, lessons learned management systems are part of the knowledge creation loop for development projects.

\subsection{KM practices in development projects}

Codification of Knowledge: Post Project Reviews (PPR) are the most widely used tool for capturing and codifying project knowledge. The limitation of access to the reports however, might reduce the utilization of lessons learned in future projects. Few of the projects use online tools to store, access and disseminate project reviews and documentation despite the advantages these might provide in utilising lessons learned. The use of PPRs for harvesting knowledge and documenting lessons learned has been discussed in literature (Tan et.al, 2006; Carrillo, 2005). Case Study 2 had a formal information management strategy which provides a framework for capturing and codifying project knowledge. Project documentation provided showed actual planning for information management such as the establishment of an intranet portal, procedures for uploading documentation and processes of managing information. Case Study 1 uses documentation, email, and an information resource centre as primary methods of managing information. Case Study 3 implements a uniform data sharing protocol which facilitates an information storage and exchange system. Case Study 4 uses an intranet to collect, store, organise, and disseminate critical information to utilities in Africa. Document examination shows that it is difficult for the case studies to separate between information management and knowledge management. Sometimes references to knowledge management during interviews are in actual fact information management conceptualisations. Lueg (2001) and Thay (2002) have documented the differences between information management and knowledge management;

Communities of practice and Networking: Communities of practice are used by project teams to facilitate knowledge exchange. Interviews and documentation provide clues as to the nature of COPs in projects. The observed COPs are formed around project activities and expertise. 
Projects use stakeholders forum as platforms for sharing knowledge. One of the projects uses a joint forum of the countries bordering the Nile to facilitate collaboration. The benefits of communities of practice have been documented in literature (Lave and Wenger,1991; Wenger et al., 2002). Conferences and seminars provide projects with opportunities to share knowledge and access best practices in the project area. Collaboration and networking among projects working in the Africa region has been crucial in enabling projects learn from what others are doing and also adapt their practices to local conditions;

\subsection{Problems of KM in development projects}

The knowledge management problems identified in the projects centre around technology, strategy, definition of success criteria and lack of visible management support. Out of the four cases, only Case Study 2 and 3 incorporate technology as a component part of their project activity. For the rest, technology use for managing knowledge is moderate. Technology is a great enabler of project processes. A variety of technologies exist which could drive KM within projects. Tirwana and Bush (2001) documented KM tools and technologies that are useful for development projects. The case studies are clearly aware of knowledge management and its' benefits but there is a lack of strategy for achieving measurable results. Winter et al (2006) highlight the importance of a KM strategic process as a learning system. They argue that knowledge sharing has to be strategic to make sense. In the absence of a strategy for sharing knowledge, development projects may be handicapped in maximising the full potentials of KM opportunities. Furthermore, the criteria for measuring or defining success vary from project to project. Even despite this, there is still an unclear notion of what constitutes success at the end of a project among the cases studied. The aim of KM is to focus its processes on those goals of the project which are important for achieving objectives. If success criteria are not spelt out clearly, KM strategies cannot successfully be applied to leverage the project process. Moreover, for $\mathrm{KM}$ to take root in an organisation, top management must be seen to support those KM processes that would be beneficial to the project process. The case study interviews reveal that most $\mathrm{KM}$ processes are informal, self organising and less structured. Only Case Study 2 and 3 have articulated a clear management support for KM and also designed strategies for creating, sharing and codifying knowledge.

\section{Discussion}

The findings of this research provide clues relating to the state of knowledge management in development projects. The general KM notion is that project success is directly related to knowledge sharing. This may not be true in some sense. During the process of this study, it was discovered that knowledge sharing does not always translate into project success. Knowledge sharing has to be strategic and focused to make sense. Knowledge is constantly 
being created and shared within projects but still many projects are failing. Where the real problem may lie for development project teams is how to contextualise and utilise such knowledge to achieve results. In essence, project teams are struggling on how to manage what they know and utilise it strategically. This research therefore proposes that there is a difference between knowledge sharing and knowledge management. Knowledge sharing is a component of $\mathrm{KM}$. One is not the other and both are not one.

One of the issues that were not highlighted by the case studies is benchmarking. Very little benchmarking is done among development projects. In reality, the two major drivers of benchmarking in the commercial world are revenue and customer focus (APQC, 2009). It might be that the non-profit nature of development projects is responsible for this. However, benchmarking has become very closely aligned with knowledge management because both are concerned with adopting and spreading best practice. It therefore makes sense if development projects can begin to structure their project processes and KM programs to include benchmarking activities. In addition, there is evidence from the case studies suggesting that decisions on what technologies to use for managing project knowledge were not clearly articulated. Given that this can make a considerable difference in project knowledge sharing and outcomes, it is important that development projects from the beginning, implement a clearcut technology policy that will enhance and not restrict knowledge sharing. Carrillo (2005) recommends that projects should have a strategy for capturing and formalising knowledge. This is in consonance with Sowards (2005) view that projects need to capture knowledge during the project and not just at the end of the whole process. Capturing and leveraging project knowledge needs a strategy centred around the following areas:

1. Knowledge mapping: Knowledge mapping involves finding out knowledge critical to the project and where they likely reside, who has such knowledge and how to leverage this for corporate benefit. One way of mapping knowledge is through meetings and brainstorming sessions. Gibbons et al (1994) postulated that knowledge identification and knowledge creation take place in problem-solving scenarios. Meetings and brainstorming sessions could provide a clue to critical knowledge areas of the project and enable managers to identify where knowledge resides and the strategies for leveraging such knowledge. None of the cases presented a clear evidence of having mapped their knowledge domains to identify critical knowledge and how to leverage these ;

2. Appropriate technology: It is important that the technology needs of a development project are diagnosed at the beginning to enable these to be implemented through the whole process. At the commencement of a project, technology tools support the sense 
making process as the staff try to make meaning of documentation and what they are supposed to do, (Odhiambo et al.,2003). Technology enables the search and retrieval of information that relates to similar projects of the past. Project databases and intranets offer a lot of information on related resources such as post project reviews which might contain lessons learned and mistakes made and this constitutes important knowledge for current projects. Although cases studied utilise technology for project purposes, there were no clear-cut processes for technology adoption;

3. Effective and relevant information management system: DPs need to put into place effective information management systems to enhance KM practices. Such IM systems may include a mechanism for identifying and capturing information from relevant sources, availability of data publicised at various levels through press articles, media coverage, project fliers and stakeholder meetings in line with project work plan, training workshops on the methods, value and relevance of data collection, information tailored to the needs of specific user groups prepared and supplied on demand (DFID, 2003);

4. Make the project cycle knowledge-driven: Project managers were of the view that the basic instrument for managing DPs-the project cycle should be knowledge-driven to make any impact. The implication is that KM processes should be embedded in the project process (cycle) and in this way, the project process would be knowledge intensive and knowledge focused. A variety of models and frameworks exist in literature which can help development projects enable KM. Gibbons et al (1994) work on knowledge production identified two types of knowledge production. Mode 1 is academic and research driven while mode 2 is problem-driven and multidisciplinary. The latter is mostly useful for development projects. Nonaka and Takeuchi (1995) identified four distinct phases of knowledge creation; Internalisation, Socialisation, Externalization and Combination. Three of these phases (socialization, externalization and combination) involve social interaction among project members. (Chua, 2003) identified the structural dimension of knowledge creation, the relational dimension and the cognitive dimension. The relational and cognitive dimension relate mostly to development project activity;

5. Contextualise knowledge: Knowledge must be put into the context where it makes more meaning. Improving the KM practices of DPs would require designing strategies to situate knowledge within relevant contexts. Swan and Newell (2000) recognise the need for organisations to focus knowledge in those critical areas where it is needed and to provide an appropriate context for translating the benefits of knowledge sharing within the organisation. This involves converting knowledge from an abstract concept to a practical reality. The ways to do this have been discussed by Szulanski (1996); and 
6. Community building: Collaboration is a major feature of most DPs used as case studies. Using communities to leverage project knowledge is a way for improving KM practices. The reasons why individual project members would decide to share knowledge and participate in communities and assimilate knowledge has not been well understood. However, recent studies have shown that motivation is a key factor in sharing knowledge in communities. Knowledge doesn't flow easily even when project teams make concerted efforts (De Long and Fehey, 2000). There is evidence relating to the existence of communities of practice within the case studies. Development project teams should pay closer attention to these communities and look for ways to leverage their capabilities. Management should be seen to encourage the growth and development of communities of practice within the project as this holds the potential for achieving project expectations. One of the difficulties of communities of practice is management buy-in and how to translate knowledge sharing from the community into project work processes. A knowledge management strategy that articulates the benefit realisation process of knowledge sharing would tend to solve this problem. Overall, there is the sense that development project teams are beginning to buy into the knowledge management agenda although this is still in the early stages. Future researches may serve to reveal the maturity level of development projects as regards the adoption of knowledge management strategies and probably how these translate to project performance.

The major constraints of this research are the following:

(1) Investigating Sub-Saharan Africa in development activity is a difficult area due to the low level of technology, poor infrastructure, and conflict, low level of education, ignorance and difficulty in collecting data. This informed the use of four case studies as well, because the researchers considered the difficulty of visiting various organisations in relation to transport, poor technology and willingness to provide information.

(2) This is one of the few studies carried out in the area of development projects. It is therefore recommended that more studies be carried out to confirm or reject the assumptions and findings of this research. 


\section{References}

Abom, B. (2004). Social capital, NGOs, and development: a Guatemalan case study.

Development in practice, vol.14(3),342-353

Alavi M, and Leidner D (2001) Knowledge management and knowledge management systems: conceptual foundations and research issues. Management Information Systems Quarterly 25(1), 107-36.

Ancona D and Caldwell D (1992) Bridging the boundary: External activity and performance in organisational teams. Administration Science Quarterly 37(4), 634-665.

APQC(2009). Benchmarking in organisations. Webinar presentation made on the $8^{\text {th }}$ of December, 2009. Houston: APQC.

Baker, JL (2000) Evaluating the impact of development projects on poverty: a handbook for practitioners. Washington, DC: World Bank

Bennet R (2000) Local and regional economic development : renegotiating power under Labour. Ashgate, Aldershot.

Blacker F (1995) Knowledge, knowledge network and organisations: an overview and interpretations. Organisation Studies 15(6), 1021-46.

Boisot M (1987) Information and Organisations: The Manager as Anthropologist. Fontana/Collins, London.

Brown, S., and K. Eisenhardt (1997). The Art of Continuous Change: Linking Complexity Theory and Time-paced Evolution in Relentlessly Shifting Organizations. Administrative Science Quarterly, 42, 1-34.

Burger R and Owens T (2006) Examining accountability mechanisms in development projects of Ugandan NGOs: Comparing the merits of community participation vs. government and donor monitoring. University of Stellenbosch, Stellenbosch.

Carrillo P (2005) Lessons learned practices in the engineering, procurement and construction sector. Engineering, Construction and Architectural Management 12(3), 236-250.

Carroll, J. S and Johnson, E. J. (1990) Decision research: A field guide. Newbury Park,. CA: Sage.

Chua A (2003) Knowledge Sharing: a game people play. Aslib Proceedings 55(3),117-129. 
Cusworth J, and Franks T (1993) Managing projects in developing countries. Essex: Longman Scientific and Technical.

Dalgleish S (2003). Are product development projects doomed to fail?.Quality Magazine [WWW document] http://www.qualitymag.com/CDA/Archives (accessed 23 May 2006).

Deardorff A (2000) Deardorff's Glossary of International Economics [WWW document] http://www-personal.umich.edu/ alandear/glossary/d.html. (accessed 27 August 2005).

DeLong D and Fehey $L$ (2000). Diagnosing cultural barriers to knowledge management. Academy of Management Executive 14(4),113-27.

Demerest M (1997) Understanding knowledge management, Journal of Long Range Planning 30(3), 374-84.

DFID (2003) JEWEL: Jigawa Enhancement of Wetlands Livelihood Project-project document. UNDP, Abuja.

Downs G and Mohr L (1976) Conceptual Issues in the Study of Innovation. Administrative Science Quarterly. 21, 700-14.

Garon S (2006) Space project management lessons learned: a powerful tool for success. Journal of Knowledge Management 10(2),103-112.

Gibbons M., Limoges C., Nowotny H., Schwartzman S., Scott P. and Trow M (1994). The new production of knowledge: The dynamics of science and research in contemporary society . London: Sage Publications.

Holvland, Ingie, (2003) Knowledge Management and Organisational Learning: An International Development Perspective, Overseas Development Institute, London.

Jacques J, and Ryan E (1978) Does management by objectives stifle organisational innovation in the public sector? Canadian Public Administration .21, 17-25.

Jugdev K and Müller R (2005) A Retrospective Look at Our Evolving Understanding of Project Success. Project Management Journal 36(4) 19-31.

Kakabadse N, Kakabadse A, and Kouzmin A (2003) Reviewing the Knowledge Management Literature: towards a taxonomy. Journal of Knowledge Management 7(4), 75-91.

Krogh, G, Nonaka, I and Ichijo, K(2000). Enabling Knowledge Creation: How To Unlock The Mystery Of Tacit Knowledge And Release The Power Of Innovation. Newy York: Oxford University Press. 
Lave J (1988) Cognition in Practice. Cambridge University Press, Cambridge, MA.

Liebowitz J (2001) Knowledge Management: learning from knowledge engineering. CRC Press, Boca Raton.

Lueg C.(2001) Information, Knowledge and networked minds. Journal of Knowledge Management 5(2),151-159.

McMichael, C(2004) Somali women and well-being: social networks and social capital among immigrant women in Australia. Human organisation .63(1), 88-99.

Newell S, Robertson M, Scarbrough H, and Swan J, (2002) Managing Knowledge Work. Palgrave Macmillan, London.

Nonaka I, and Takeuchi K (1995) The Knowledge Creating Company: How Japanese Companies Create the Dynamics of Innovation. Oxford University Press, Oxford.

Odhiambo F, Harrison J and Hepworth M (2003). The Use of Sense Making for Understanding the Information Needs of Informal Carers in Leicestershire: An Analysis of the Micro Moment Time Line. Library and Information Research News 27(9),0-1

Robinson HS, Carrillo PM, Anumba CJ and Al-Ghassani AM (2001) Perceptions and barriers in implementing knowledge management strategies in large construction organisations. In Proceedings of RICS Foundation Construction and Building Research Conference - COBRA 2001 (Kelly J and Hunter K, Eds), pp 451-460, Glasgow Caledonian University, Glasgow, U.K.

Rogers E and Kim J (1985) Diffusion of Innovations in Public Organisations. In Innovation in the Public Sector, ed. Richard L. Merritt and Anna J. Merritt, 85-108. Sage Publications, Beverley Hills.

Rollett H (2003) Knowledge Management: Processes and Technologies. Kluwer Academic Publishers, Boston.

Skyrme D, and Amidon D (1997) The Knowledge Agenda. Journal of Knowledge Management 1(1), 27-37.

Sowards, D (2005) The value of post-project reviews. Contractor 52(8), 35-36. 
Styhre, A and Kalling, T(2003). Knowledge sharing in organisations. Copenhagen:

Copenhagen Business School Press.

Swan J and Newell S (2000) Linking Knowledge Management and Innovation. European Conference on Information Systems, Wien.

Szulanski G (1996) Exploring internal stickiness: Impediments to the transfer of best practice within the firm. Strategic Management Journal 17,27-43.

Tan H, Carrillo P, Anumba C, Kamara J, Bouchlaghem D and Udeaja C (2006). Live capture and reuse of project knowledge in construction organisations. Knowledge Management Research \& Practice (2006) 4, 149-161.

Thay S (2002)The differences between information and data [WWW document] http://www.brint.com/wwwboard/messages/10525.html (accessed 08 February 2004).

Tiwana A and Bush, A (2001). A social exchange architecture for distributed Web communities. Journal of Knowledge Management 5(3), 242-249 .

Thompson V (1965) Bureaucracy and Innovation. Administrative Science Quarterly 10, 1-20.

von Zedtwitz M (2003) Post-project reviews in R\&D. Research-Technology Management $.46(5), 43-49$.

Wenger E, McDermott, R and Snyder W (2002) Cultivating Communities of Practice: a guide to managing knowledge. Harvard Business School Publishing, Boston.

Wiig K (2000) Knowledge management: an emerging discipline rooted in a long history. Knowledge Horizons. MA: Butterworth-Heinemann, Boston.

Wiig K (1997) Knowledge Management: An Introduction and Perspective. Journal of Knowledge Management .1, 6-14.

Winter M, Smith C, Cooke-Davies T and Cicmil S (2006) The importance of 'process' in Rethinking Project Management: The story of a UK Government-funded research network .International Journal of Project Management .24(8),650-662.

de Witt A (1998) Measurement of project success. International Journal of Project Management .6 (3), 164-170.

Yahya M (2007) Polio vaccines_-"no thank you!" barriers to polio eradication in Northern Nigeria. African Affairs 106, 185-204.

Yin ,R. (1994) Case study research: Design and methods. $2^{\text {nd }}$ ed. Beverly Hills, CA: Sage Publishing. 



\begin{tabular}{|c|c|}
\hline Knowledge Sharing & $\begin{array}{l}\text { How does informal discussion help you solve project problems ? } \\
\text { Do your work colleagues play vital roles in helping you come to know } \\
\text { your job very well? } \\
\text { Are there times when you help other colleagues with information on a } \\
\text { particular problem? } \\
\text { Do you belong to any informal groups in your project? } \\
\text { Do you rely on your project group for information and career goals? } \\
\text { What are the external sources of personal improvement available to } \\
\text { you? }\end{array}$ \\
\hline Innovation & $\begin{array}{l}\text { Do you come up with new ideas and ways of doing things during } \\
\text { discussions? } \\
\text { What are your views about group discussions as relating to sharing } \\
\text { information with colleagues on the project? Would you say this helps } \\
\text { generate new ideas for your project? } \\
\text { Since belonging to the project have you witnessed significant changes } \\
\text { in the way you work? } \\
\text { What major achievements and significant changes have happened on } \\
\text { the job as a result of interaction with colleagues? }\end{array}$ \\
\hline Completion times & $\begin{array}{l}\text { Do you feel your project completes its assignments on time? Explain } \\
\text { and give reasons. } \\
\text { What factors do you think are responsible for your project completing } \\
\text { on time? } \\
\text { Do you think an increase in your understanding of the project activities } \\
\text { and tasks through sharing knowledge helps you complete tasks and } \\
\text { the project on time? }\end{array}$ \\
\hline Project Success & $\begin{array}{l}\text { What roles do knowledge sharing and management play in helping } \\
\text { your project succeed? } \\
\text { Is knowledge sharing a major factor in your project's success? } \\
\text { If the project is a failure, why do you think it failed? } \\
\text { Are there certain processes within the project that failed, or plans } \\
\text { which failed to be executed and what do you think was responsible for } \\
\text { this failure? }\end{array}$ \\
\hline $\begin{array}{l}\text { Generation of new } \\
\text { knowledge }\end{array}$ & $\begin{array}{l}\text { In your estimation, how does your project or project group generate } \\
\text { new knowledge? } \\
\text { What factors would you say are responsible for new ideas in your } \\
\text { project? } \\
\text { Do you feel you have learnt a lot by sharing knowledge and } \\
\text { discussing with colleagues since joining the project? } \\
\text { How has this helped you in solving project problems? }\end{array}$ \\
\hline Operational Efficiency & $\begin{array}{l}\text { Do you think your project operates at maximum capacity as a result of } \\
\text { sharing knowledge? } \\
\text { Does sharing knowledge with colleagues help you utilise staff and } \\
\text { resources effectively? Please explain }\end{array}$ \\
\hline
\end{tabular}




\begin{tabular}{|c|c|c|c|c|c|c|c|c|c|}
\hline \multicolumn{2}{|c|}{ Project Information } & \multicolumn{5}{|c|}{ KM Impact Variables } & \multicolumn{3}{|c|}{ KM Practices } \\
\hline $\begin{array}{l}\text { Case } \\
\text { Study } \\
\text { No. }\end{array}$ & Project & Innovation & Completion Times & Project Success & $\begin{array}{l}\text { Operational } \\
\text { Efficiency }\end{array}$ & $\begin{array}{l}\text { Generation of } \\
\text { New Knowledge }\end{array}$ & $\begin{array}{l}\text { Codification/ } \\
\text { Technology }\end{array}$ & $\begin{array}{l}\text { Community/ } \\
\text { Networking }\end{array}$ & $\begin{array}{l}\text { Lessons } \\
\text { Learned }\end{array}$ \\
\hline 1 & Poverty reduction & $\begin{array}{l}\text { Communities of } \\
\text { Practice based }\end{array}$ & $\begin{array}{l}\text { Communities of } \\
\text { Practice; Team building }\end{array}$ & $\begin{array}{l}\text { Alignment of KM } \\
\text { practices to } \\
\text { corporate } \\
\text { objectives }\end{array}$ & $\begin{array}{l}\text { Clearly defined } \\
\text { processes; } \\
\text { Performance } \\
\text { Management }\end{array}$ & $\begin{array}{l}\text { Capturing } \\
\text { knowledge from } \\
\text { COPs }\end{array}$ & $\begin{array}{l}\text { Post Project } \\
\text { Reviews; No } \\
\text { central storage } \\
\text { system; Email; } \\
\text { Website }\end{array}$ & $\begin{array}{l}\text { COPs among } \\
\text { clients; } \\
\text { Conferences; } \\
\text { Workshops }\end{array}$ & $\begin{array}{l}\text { Use PPR reports to } \\
\text { improve future } \\
\text { projects }\end{array}$ \\
\hline 2 & $\begin{array}{l}\text { Environmental conflict } \\
\text { resolution }\end{array}$ & $\begin{array}{l}\text { COPs, Incentive } \\
\text { systems, } \\
\text { Collaborative project } \\
\text { design, development } \\
\text { and delivery. }\end{array}$ & $\begin{array}{l}\text { Networking and } \\
\text { institutional } \\
\text { collaboration critical to } \\
\text { driving completion } \\
\text { times }\end{array}$ & $\begin{array}{l}\text { Developing and } \\
\text { implementing a } \\
\text { coherent KM } \\
\text { strategy and } \\
\text { implementing } \\
\text { across enterprise }\end{array}$ & $\begin{array}{l}\text { Well defined } \\
\text { processes and } \\
\text { integration of } \\
\text { Balanced Score } \\
\text { Card and KM }\end{array}$ & $\begin{array}{l}\text { Post Project } \\
\text { Reviews, } \\
\text { Documentation } \\
\text { and information } \\
\text { Management }\end{array}$ & $\begin{array}{l}\text { Extensive } \\
\text { documentation \& } \\
\text { Information } \\
\text { management; Use } \\
\text { of global portal; } \\
\text { Database of } \\
\text { environmental } \\
\text { livelihoods }\end{array}$ & $\begin{array}{l}\text { Stakeholder forum } \\
\text { used as a platform } \\
\text { for facilitating } \\
\text { COPs; Networking } \\
\text { with similar } \\
\text { projects and } \\
\text { donors in the } \\
\text { region }\end{array}$ & $\begin{array}{l}\text { Lessons learned } \\
\text { documented } \\
\text { frequently and } \\
\text { used for current } \\
\text { and future projects }\end{array}$ \\
\hline 3 & Nile-Basin development & $\begin{array}{l}\text { Technology and } \\
\text { Collaboration }\end{array}$ & $\begin{array}{l}\text { Technology, networking } \\
\text { and training critical to } \\
\text { completion times }\end{array}$ & $\begin{array}{l}\text { Effective } \\
\text { communication } \\
\text { and collaboration }\end{array}$ & $\begin{array}{l}\text { Staff experience, } \\
\text { competence and } \\
\text { qualifications }\end{array}$ & $\begin{array}{l}\text { Utilises portal } \\
\text { technology to } \\
\text { capture, analyse } \\
\text { and transform } \\
\text { knowledge }\end{array}$ & $\begin{array}{l}\text { Post Project } \\
\text { Reviews, technical } \\
\text { specifications, } \\
\text { Uniform data } \\
\text { sharing protocol }\end{array}$ & $\begin{array}{l}\text { Joint forum of Nile- } \\
\text { countries; } \\
\text { Networking of } \\
\text { technical teams of } \\
\text { Nile countries }\end{array}$ & $\begin{array}{l}\text { LL used to improve } \\
\text { trans-boundary } \\
\text { cooperation and } \\
\text { also feed into } \\
\text { technical } \\
\text { implementation }\end{array}$ \\
\hline 4 & $\begin{array}{l}\text { Water utilities capacity } \\
\text { building }\end{array}$ & $\begin{array}{l}\text { Organizational } \\
\text { culture, linkages and } \\
\text { cross-country } \\
\text { networking }\end{array}$ & $\begin{array}{l}\text { Knowledge base and } \\
\text { institutional capacity to } \\
\text { leverage knowledge }\end{array}$ & $\begin{array}{l}\text { Familiarity with } \\
\text { best practices and } \\
\text { leveraging these } \\
\text { for project use }\end{array}$ & $\begin{array}{l}\text { Efficient resource } \\
\text { allocation, project } \\
\text { planning and team } \\
\text { building }\end{array}$ & $\begin{array}{l}\text { Lessons learned } \\
\text { management } \\
\text { systems }\end{array}$ & $\begin{array}{l}\text { Stakeholder } \\
\text { consultation \& } \\
\text { workshop } \\
\text { outcomes codified } \\
\text { and stored; Use a } \\
\text { web-portal to } \\
\text { organize } \\
\text { collaborative } \\
\text { efforts }\end{array}$ & $\begin{array}{l}\text { Foster } \\
\text { collaboration } \\
\text { among water } \\
\text { utilities of Africa }\end{array}$ & $\begin{array}{l}\text { LL focus is on } \\
\text { improving the } \\
\text { services of water } \\
\text { utilities in Africa }\end{array}$ \\
\hline
\end{tabular}





\begin{tabular}{|l|}
\hline $\mathbf{R}$ \\
$\mathbf{Y}$ \\
$\mathbf{L}$ \\
$\mathbf{E}$ \\
\\
\\
\hline $\mathbf{P}$ \\
$\mathbf{O}$ \\
$\mathbf{L}$ \\
$\mathbf{A}$ \\
$\mathbf{N}$ \\
$\mathbf{Y}$ \\
$\mathbf{I}$ \\
\hline
\end{tabular}

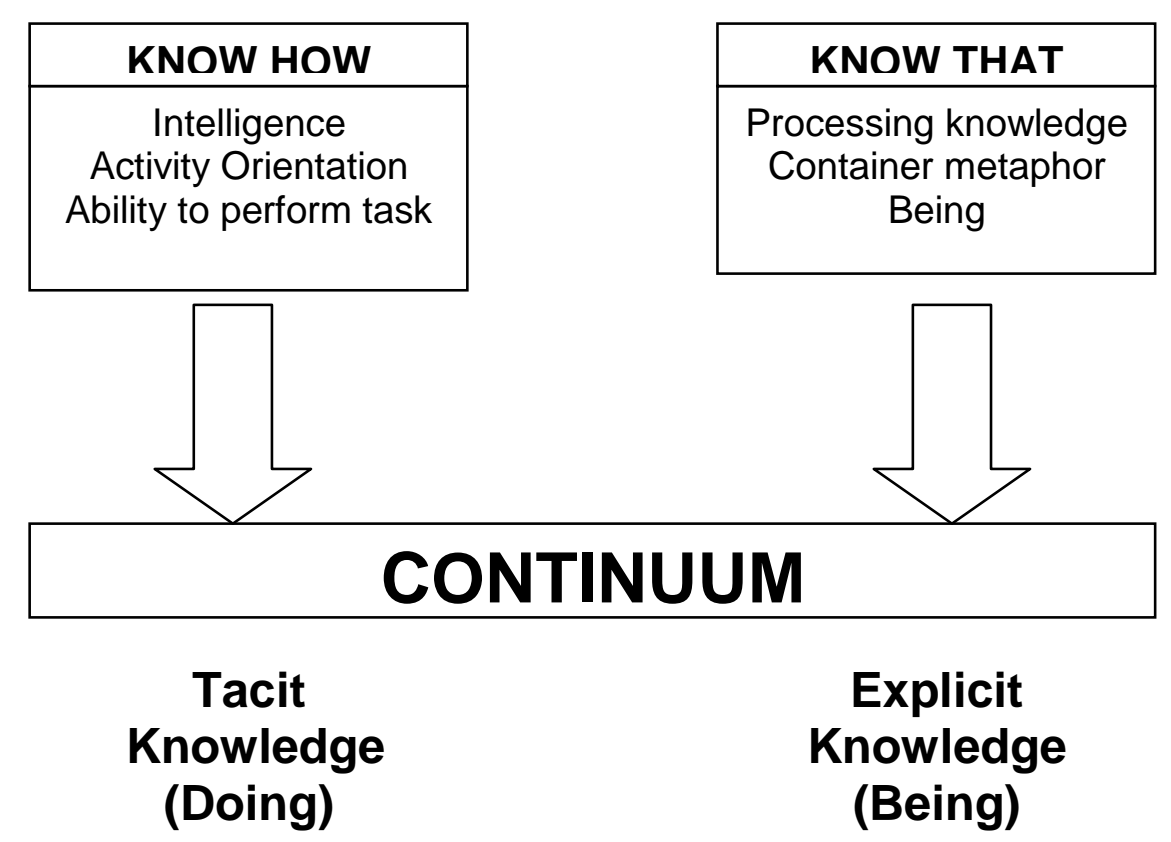



Table 1: Relationship between the capture, sharing, reuse and maintenance of knowledge (Tan et al, 2006)

Table 2: Case Study Interview Schedule

Table 3: Analysis of Knowledge Management in development projects

Figure 1: The concept of tacit and explicit knowledge (Jashapara, 2003) 